\title{
A könyvtáros kompetenciák erősítésének lehetőségei Továbbképzések a Könyvtári Intézet tanfolyami kínálatában
}

\section{Kompetenciák régen és most}

Dávid Antal a múlt század harmincas éveiben még nem használhatta ugyan a napjainkra igen elterjedtté vált 'kompetencia' kifejezést, de mindazt a szakértelmet, hozzáértést, alkalmasságot ${ }^{1}$, amelyet ő fogalmazott meg a könyvtárosokkal szembeni elvárásként, bátran sorolhatjuk ma is szakmánk kompetenciái közé: „Hogy rátermettséggel kezdjük, jó emlékezőtehetség, friss eszmetársító készség, gyors és higgadt ítélőképesség nélkül hamarosan nagyon idegenül és szerencsétlenül fogja magát érezni az ember a könyvtári szolgálatban. [...] Mindenekelőtt bírnia kell a Szentlélek pünkösdi ajándékát, a nyelvek adományát. [...] A tudományok iránti érdeklődése legyen széleskörü és élénk, mint valamely műkedvelöé, de tájékozottsága legalább olyan mély, hogy a szellemi pelyvát el tudja választani a tiszta búzától, és segíteni tudjon ne csak az érdeklődő laikusnak, hanem a komoly kutatónak is. [...] Minden vitán felül kétségtelen [...], hogy holtig megőrzött tanulási vágy nélkül jó könyvtáros el sem képzelhető. Morális téren: egyesüljön a könyvtárosban a szerzetesi igénytelenség és alázatosság a nagyvilági fölényességgel, és mindenek felett legyen meg benne a veleszületett és önneveléssel tökéletesített segítőkészség. Tudjon tiszta szívvel örülni azokkal, akik segítsége révén lélekben gazdagodtak és érezzen őszinte hálát azok iránt, akiknek szolgálatára lehetett." ${ }^{2}$

Milyen kompetenciákat vár el a 21. század a könyvtáros szakma képviselöitől? Az IFLA 2013-ban kiadott és évente frissített trendjelentése $i^{3}$ mind-mind

1 http://janus.ttk.pte.hu/tamop/tananyagok/curriculum/iii_1_a_kompetencia_sz_jelentse. html (2019. október 4.) - a 'kompetencia' kifejezés jelentései a köznyelvben.

${ }^{2}$ Dávid Antalnak az 1937. évi könyvtárosképző tanfolyamon elhangzott definícióját Káplány Géza idézi a Könyvtárak korszerü rendezése és fejlesztése (Bp., A Technológiai Könyvtár Barátainak Egyesülete, 1943.) címü kötetben, 1. 4. p. Dávid Antal vonatkozó előadásának szövege ugyan megjelent nyomtatásban is (Könyvtári előadások. Az 1937. évi február 1. - márc. 23. között tartott könyvtárosképző tanfolyam előadásainak összefoglaló vázlata kéziratként. Bp., kiadták a tanfolyam hallgatói, 1937. II. Dávid Antal: Gyakorlati könyvtártan. 1-42. p.), a szó szerinti idézet azonban ebben az anyagban nem szerepel, így valószínüsíthető, hogy Káplány Géza magát az 1937. évi könyvtárosképző tanfolyamon tartott előadást hallva rögzítette a szöveget. Erre utal(hat) az oldal alján a lábjegyzet is: „Dr. Dávid Antalnak az [...] előadásából vett idézet, az elöadó külön engedélyével közölve."

${ }^{3}$ https://trends.ifla.org (2019. október 4.) Magyar nyelven 1.: IFLA trendek - röviden. Ford.: Hegyközi Ilona. Bp., MKE, 2017. 20 p. http://mke.info.hu/wp-content/uploads/2017/10/iflatrendek_roviden_V6.pdf (2019. október 4.) 
olyan új kihívásokat fogalmaznak meg - az információhoz való hozzáférés a digitális univerzumban, online tanulás, az adatvédelem és a tájékoztatáson alapuló beleegyezés fogalma, hálózatba kapcsolt társadalmak, globális információs gazdaság -, amelyekhez az egész életen át tartó tanulás jegyében a könyvtárosok számára is elengedhetetlenül szükséges meglévő kompetenciáik fejlesztése és újabbak elsajátítása, kialakítása. Hasonló elvárásokat állít elénk a 2016 óta negyedik ipari forradalomnak ${ }^{4}$ nevezett folyamat, annál is inkább, mivel Bojár Gábor szellemes megközelítésében ez legalább annyira informatikai forradalom is, a sorban a beszéd (az összetett információ átadásának képessége) és az írás (az információ tárolásának módja) után a harmadik (a végtelen információ feldolgozása), mint amennyire az ipari forradalom 4.0 változata $^{5}$. Ragnar Audunson véleménye ${ }^{6}$ szerint azt a két trendet - a digitalizálást és a könyvtárak közösségi térré válását -, amelyek alapján a közvélemény gyakran tévesen úgy ítéli meg, hogy könyvtárosokra már nem nagyon van szükség, szakmánk éppen ellenkezöleg értelmezi: az első felszabadítja a könyvtárosokat a fizikai térben történő szolgáltatás kötöttségeitől, így erősebben összpontosíthatnak a szakma önértelmezésére, valódi küldetésére, a második kialakítása során pedig éppen a könyvtárosok azok, akik megteremtik a fenntartható nyilvános szférát, a társadalmi részvétel színterét - mindehhez nyilvánvalóan elengedhetetlen a képzésben való részvétel, a kompetenciák karbantartása és fejlesztése.

\section{A továbbképzés megújult jogszabályi háttere}

A könyvtári terület 2017 végén lezajlott jogszabályalkotási és -módosítási folyamata a könyvtárosok továbbképzésére vonatkozó rendeleteket is érintette: 2018. január elején életbe lépett a kulturális szakemberek továbbképzését szabályozó rendeletcsokor ${ }^{7}$ : egy-egy új miniszteri rendelet szabályozza a továbbképzés körülményeit és a képzések engedélyeztetésének igazgatási szolgáltatási díját, egy új kormányrendelet pedig a továbbképzések nyilvántartásba vételének szabályait. Emellett köztudott, hogy már korábban, 2012. január 1-jével megváltozott

\footnotetext{
${ }^{4}$ A témáról 1. pl. a Magyar Tudomány közelmúltban megjelent tematikus számát, amelyet a szerkesztők A munka jövője, a tudomány és a tanulás a 21. század világában címmel állítottak össze: 2018. 1. sz. 3-98. p.

${ }^{5}$ Bojár Gábor: Negyedik ipari vagy harmadik informatikai forradalom? Az információ sok ezer éves hatalma. $=$ MagyarTudomány, 2018. 1. sz.37-46.p.https://doi.org/10.1556/2065.179.2018.1.4

${ }^{6}$ Audunson, Ragnar: Do we need a new approach to library and information science $?=$ Bibliothek: Forschung und Praxis, 2018. 2. sz. 357-362. p. Ism. Tóth Máté. https://doi.org/10.1515/bfp-2018-0040

7 32/2017. (XII. 12.) EMMI rendelet a kulturális szakemberek továbbképzéséről. http://njt. hu/cgi_bin/njt_doc.cgi?docid=205791.347787; 378/2017. (XII. 11.) Korm. rendelet a kulturális szakemberek szakmai továbbképzésének nyilvántartásba vétel szabályairól. http://njt.hu/cgi_bin/ njt_doc.cgi?docid=205785.347559; 39/2017. (XII. 29.) EMMI rendelet a kulturális szakemberek szakmai továbbképzési programjának nyilvántartásba vételével [...] összefüggő igazgatási szolgáltatási díjról. http://njt.hu/cgi_bin/njt_doc.cgi?docid=206331.350528 (2019. október 4.)
} 
az 1997. évi CXL. törvény ${ }^{8}$ továbbképzésre vonatkozó 94. paragrafusának (4) bekezdése: azóta a továbbképzésben való részvétel nem kötelező, „csak” lehetőség.

A kulturális szakemberek továbbképzését szabályozó korábbi NKÖM rendelet ${ }^{9}$ hatálya 2018. január 1-jével megszünt, az új miniszteri rendelet ${ }^{10}$ elöírásait nyilvános könyvtár, országos szakkönyvtár, megyei hatókörü városi könyvtár közalkalmazotti vagy munkaviszony alapján, szakmai munkakörben, legalább hat órában foglalkoztatott közép- és felsőfokú végzettségủ szakemberei továbbképzésének tervezése, lebonyolítása, finanszírozása során kell alkalmazni. Az új rendelet az intézményvezetőktől a rendelet 3. és 4. paragrafusában pontról pontra meghatározott tartalmú ötéves képzési terv és éves beiskolázási terv készítését várja el - anélkül, hogy rendelkezne a tervek fenntartóval való elfogadtatásáról vagy központi nyilvántartásba való beküldéséről. Nem változtak a korábbi rendelet elörrásaihoz képest a továbbképzésben való részvétel megvalósulásának formái: hatósági nyilvántartásba vett, tanfolyam jellegủ szakmai továbbképzés; OKJ-s képzés; államilag elismert nyelvvizsga; az adott kulturális területnek megfelelő alap- és mesterképzés, szakirányú továbbképzés, doktori képzés; nemzetközi program, szerződés alapján szervezett szakirányú továbbképzés. Mindezek mellett a továbbképzés teljesítéseként a rendelet elfogadja az európai uniós projektek keretében - általában ingyenesen biztosított - képzések elvégzését is. A jogszabály 7. paragrafusa megállapítja, hogy a kulturális szakemberek a képzési és a beiskolázási terv alapján csak olyan továbbképzésben való részvételre kötelezhetők, amelynek költségeit európai uniós vagy intézményi hozzájárulás fedezi.

\section{A Könyvtári Intézet szerepe a továbbképzésben}

A Könyvtári Intézet azzal tudja segíteni a könyvtáros társadalmat az egész életen át tartó tanulás folyamatában, hogy - jogszabályi kötelezettségeinek ${ }^{11}$ eleget téve - rendszeresen megújuló továbbképzési kínálatot nyújt számára. 2017 szeptembere óta a továbbképzések megvalósítását két igen fontos tényező segíti. Egyrészt az Országos Széchényi Könyvtárnak köszönhetően teljesen megújult képzéseink helyszine: mind a hagyományos, mind a számítógépes oktatóterem felújításra került, a befogadóképesség 30-30 före bővült; mindkét terem modern bútorzatot és technikai felszerelést kapott.

${ }^{8} \mathrm{http} / / /$ njt.hu/cgi_bin/njt_doc.cgi?docid=30818.370103 (2019. október 4.)

9 1/2000. (I. 14.) NKÖM rendelet a kulturális szakemberek szervezett képzési rendszeréről, követelményeiröl és a képzés finanszírozásáról. http://njt.hu/cgi_bin/njt_doc. cgi?docid=47768.238710 (2019. október 4.)

${ }^{10}$ L. a 7. sz. jegyzet első hivatkozását.

${ }^{11}$ 1997. évi CXL. törvény a muzeális intézményekröl, a nyilvános könyvtári ellátásról és a közművelődésről, 60. § (3), (4) bek. http://njt.hu/cgi_bin/njt_doc.cgi?docid=30818.370103; 30/2014. (IV. 10.) EMMI rendelet az országos múzeum, az országos szakmúzeum, a nemzeti könyvtár, az országos szakkönyvtár és az állami egyetem könyvtárának kiemelt feladatairól, 8. § (3) bek. http://njt.hu/cgi_bin/njt_doc.cgi?docid=168674.348436 (2019. október 4.) 


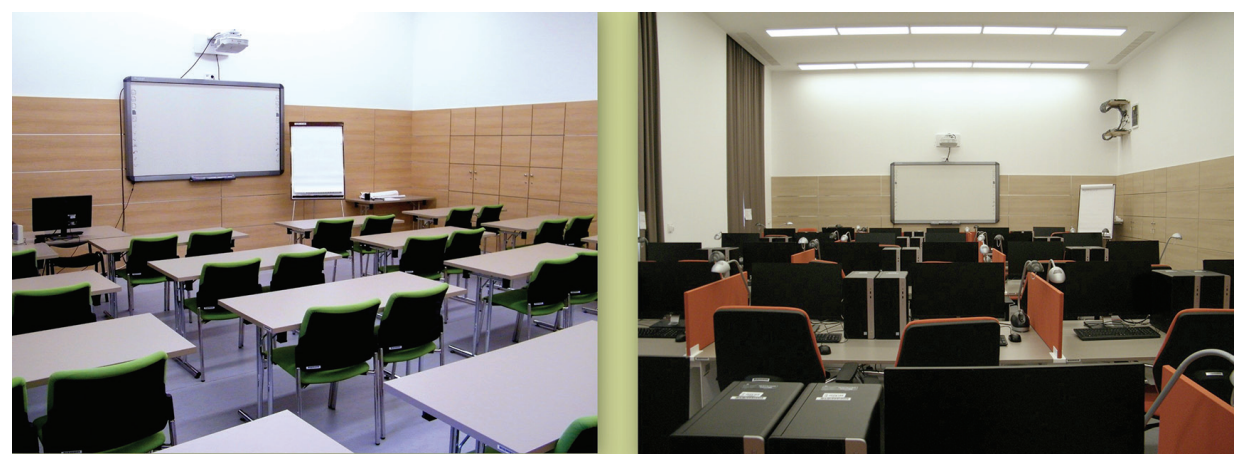

1. ábra. A Könyvtári Intézet felújított oktatótermei

Másrészt az állami költségvetési törvényekbe ${ }^{12}$ (újra) bekerült az a költségvetési sor, amelynek összege a kulturális szakemberek továbbképzésére fordítható, és ezekből az összegekből az ágazati irányítás döntése alapján 2017-ben és 2018ban 30 millió forintot, 2019-ben pedig 15 millió forintot a Könyvtári Intézet használhatott fel. A felhasználást mindhárom alkalommal komoly tervezési időszak előzte meg, hiszen nemcsak az volt fontos, hogy a támogatásnak köszönhetően a tanfolyamokon ingyenes részvételt biztosíthatunk a könyvtárosok számára, hanem az is, hogy lehetőségünk legyen a képzések vidéki könyvtárakba való kihelyezésére, határon túli továbbképzési programunk folytatására ${ }^{13}$, újabb továbbképzési programok engedélyeztetésre és a később engedélyeztetendő online tanfolyamok elektronikus tananyagaihoz szükséges oktatói kéziratok elkészíttetésére.

A tervezési időszakokban az igényfelmérésekről sem feledkeztünk el, ezek közül a legutóbbira, amely elektronikus formában 2018 decembere és 2019. január vége között zajlott, a nyilvános könyvtárak jegyzékén szereplő intézmények 43,1 százaléka küldött be válaszokat. A válaszadók között valamennyi könyvtártípus képviseltette magát. Kérdéseink a következö témákat járták körül: az Intézet képzéseire vonatkozó elégedettség; a képzések lehetséges helyszínei; a már engedélyezett, az engedélyezés alatt álló és a tervezett képzések iránti igények / az adott intézmény által tervezett résztvevői létszám az elkövetkező tanévek egyes féléveiben; a képzések formája; újabb továbbképzési témákra vonatkozó javaslatok. A feldolgozott válaszok eredményei szerint a képzések

12 2016. évi XC. törvény Magyarország 2017. évi központi költségvetéséröl. http://njt. hu/cgi_bin/njt_doc.cgi?docid=196082.340679; 2017. évi C. törvény Magyarország 2018. évi központi költségvetéséről. http://njt.hu/cgi_bin/njt_doc.cgi?docid=202697.340349; 2018. évi L. törvény Magyarország 2019. évi központi költségvetéséről. http://njt.hu/cgi_bin/njt_doc. cgi?docid=209695.357552 (2019. október 4.)

${ }^{13}$ A programot és beszámolóit ld. a Könyvtári Intézet honlapjának Határok nélkül menüpontjában: https://ki.oszk.hu/hatarok-nelkul (2019. október 4.) 
színvonalára és körülményeire vonatkozó elégedettség mértéke azok körében, akik a korábbiakban már részt vettek az Intézet által szervezett képzéseken, ötös skálán 4,46 volt. A képzések lehetséges helyszíneire adott válaszok szerint a kollégák 75 százaléka szívesen venne részt továbbképzéseken mind az Intézet budapesti székhelyén, mind saját megyéje megyei hatókörü városi könyvtárában. A kérdőívek kitöltésekor megjelölt tervezett résztvevői létszám alapján „népszerüségi sorrend" alakult ki már müködő és tervezett vagy engedélyeztetés alatt álló tanfolyamainkra vonatkozóan, ebben a sorrendben a legelőkelőbb helyeket az olvasásfejlesztési, a gyerekkönyvtáros, a GDPR könyvtári alkalmazására, a könyvtári minőségbiztosításra és a marketingre vonatkozó képzések foglalták el. A képzések formáját firtató kérdés esetében több válasz megjelölésére is lehetőség volt, és az eredmények azt mutatták, hogy népszerüek a jelenléti (52 százalék) és az online (68 százalék) tanfolyamok. Emellett kicsivel kevesebben jelölték meg a blended képzéseket (35 százalék) - pedig éppen e részben távoktatásban, részben személyes jelenléttel folyó képzési forma népszerüségének növelését tüztük ki célul, mert a tanfolyamaink döntö többsége gyakorlatorientált, így a képzések egy bizonyos időtartamában elengedhetetlen a személyes részvétel. A már most is blended formában müködő tanfolyamaink tapasztalatai azt mutatják, hogy a résztvevők szeretik ugyan azokat a képzéseket, amelyeknek egy részében nincs szükség a kontakt jelenlétre, de az online tanulás módszereinek elsajátítása még nem történt meg teljes mértékben. Annak érdekében, hogy ebben változást érhessünk el a könyvtáros továbbképzés területén is, az Intézet az elmúlt hónapokban benyújtott a Könyvtári Akkreditációs Szakbizottsághoz egy olyan harmincórás, formáját tekintve szintén blended továbbképzési programot engedélyeztetésre, amely az online tanulási kompetenciákat erősíti majd, e tanulási forma módszereivel és eszközeivel ismertet meg.

\section{Új tanfolyamok a továbbképzési kínálatban}

A támogatás anyagi lehetőségeit felhasználva a felmérés során érkezett témajavaslatok alapján és a minisztériumi föosztály prioritásait figyelembe véve a Könyvtári Intézet 2017 júniusa és 2019 júniusa között összesen 19 új továbbképzési program engedélykérelmét nyújtotta be a Könyvtári Akkreditációs Szakbizottsághoz. Ezek közül napjainkig 17 program engedélye érkezett meg, tehát a képzések többségét azóta már legalább egy, de inkább több alkalommal meg is valósíthattuk. Az Intézet felkérésére mind a programok kidolgozásában, mind a megszervezett képzések tanóráinak megtartásában a könyvtáros és társszakmák kiemelkedő képviselői vesznek részt. 


\begin{tabular}{|l|l|}
\hline $\begin{array}{c}\text { Az engedélyeztetés / } \\
\text { engedélyezésre be- } \\
\text { nyújtás időpontja }\end{array}$ & \multicolumn{1}{|c|}{ A továbbképzési program elnevezése és óraszáma } \\
\hline 2017. június & Irodalmi tájékoztatás online források alapján (45 óra) \\
\hline 2017. augusztus & Minőségirányítás a könyvtárban (120 óra) \\
\hline 2017. október & A kulturális közösségfejlesztés gyakorlata (60 óra) \\
\hline 2017. november & $\begin{array}{l}\text { Elektronikus tananyagfejlesztés és távoktatás könyvtári környe- } \\
\text { zetben (60 óra: 30 kontaktóra }+30 \text { óra távoktatás) }\end{array}$ \\
\hline 2017. november & $\begin{array}{l}\text { Konstruktív konfliktuskezelés hatékony tárgyalási technikákkal } \\
\text { (30 óra) }\end{array}$ \\
\hline 2017. november & $\begin{array}{l}\text { Olvasásösztönzés, olvasásnépszerüsítés, olvasásfejlesztés (60 } \\
\text { óra) }\end{array}$ \\
\hline 2018. március & $\begin{array}{l}\text { A kulturális közösségfejlesztés gyakorlata (blended) (60 óra: 30 } \\
\text { kontaktóra + 30 óra távoktatás) }\end{array}$ \\
\hline 2018. március & $\begin{array}{l}\text { Gyermekkönyvtári ismeretek új kihívásokkal - Most Te is be- } \\
\text { olvashatsz! (60 óra) }\end{array}$ \\
\hline 2018. május & $\begin{array}{l}\text { A könyvtárosok teljesítménymérése és digitális kompetenciái } \\
\text { (60 óra) }\end{array}$ \\
\hline 2018. június & $\begin{array}{l}\text { Kutatástámogatás könyvtári környezetben: szakirodalmi, tudo- } \\
\text { mánymetriai és statisztikai adatbázis-használat (45 óra) }\end{array}$ \\
\hline 2018. szeptember & $\begin{array}{l}\text { Müszaki és természettudományos szaktájékoztatás felsőfokon } \\
\text { (45 óra) }\end{array}$ \\
\hline 2018. október & Az internet archiválása mint közgyüjteményi feladat (30 óra) \\
\hline 2018. december & A zeneirodalom csúcspontjai könyvtáros szemmel (30 óra) \\
\hline 2018. december & $\begin{array}{l}\text { Felkészülés a fogyatékossággal élök korszerü könyvtári ellátá- } \\
\text { sára (60 óra) }\end{array}$ \\
\hline 2019. január & $\begin{array}{l}\text { Coaching szemlélettel a könyvtárban (30 óra) } \\
\text { kontaktóra + 18 óra távoktatás) }\end{array}$ \\
\hline 2019. február & $\begin{array}{l}\text { Utton a felhasználók felé - könyvtári marketing és rendezvény- } \\
\text { szervezés (30 óra) }\end{array}$ \\
\hline 2019. március & $\begin{array}{l}\text { A GDPR szabályainak megfelelö adatkezelés a könyvtárakban } \\
\text { (30 óra) }\end{array}$ \\
\hline 2019. május & Minőség és innováció (120 óra) \\
\hline 2019. juius & anline tanulás módszerei és eszközei (blended) (30 óra: 12 \\
\hline
\end{tabular}

1. táblázat. A Könyvtári Intézet engedélyeztetett / engedélyezésre benyújtott képzési programjai, 2017. június - 2019. június

Megújult tanfolyami kínálatunkból érdemes külön is kiemelnünk néhányat.

Az Elektronikus tananyagfejlesztés és távoktatás könyvtári környezetben elnevezésü, 60 órás blended formájú képzésünk célja, hogy a résztvevők megismerjék a digitális környezetben zajló tudáselsajátítás folyamatát és az elektro- 
nikus tananyag sajátosságait, elsajátítsák a médiaelemek elóállításának és szerkesztésének gyakorlatát, képessé váljanak szabványos SCORM kompatibilis tananyagok elkészítésére, a Moodle CMS tanári szerepkörben való használatára, tananyagok közzétételére, és a könyvtárban folyó képzések távoktatásban vagy blended learning formában történő lebonyolítására.

Konstruktiv konfliktuskezelés hatékony tárgyalási technikákkal címmel olyan képzést engedélyeztettünk, amelynek tréning-jellege alakítja a résztvevők konfliktussal kapcsolatos attitüdjét, hasznos ismeretek átadásával fejleszti konfliktuskezelési kompetenciáikat, jártassá teszi őket a képzés során ajánlott technikák alkalmazásában.

A résztvevők a Coaching szemlélettel a könyvtárban tanfolyamon olyan nyitott, támogató szemléletmódot, magatartást ismernek meg, sajátítanak el és használnak majd készségszinten mindennapjaikban és a könyvtári munka során, amely erösíti a pozitív kommunikációt, a csapatszellemet, növeli a munka hatékonyságát, segíti az egymáshoz való mindennapi stresszmentes, konfliktusmentes kapcsolódást. A képzésen résztvevők mélyebbre jutnak önmaguk megismerésében, fejlesztik saját erőforrásaikat, és képessé válnak arra, hogy mások erőforrásait is feltérképezzék és hatékonyan használják a munkahelyi környezetben.

Az Olvasásösztönzés, olvasásnépszerüsités, olvasásfejlesztés elnevezésü tanfolyamunk során a résztvevők megismerik az olvasásfejlesztés feladatrendszerének elemeit, jártassá válnak a magyar és más európai könyvtárak olvasáspedagógiai gyakorlatának alkalmazásában; elsajátítják azokat a módszereket és eszközöket, amelyek a különböző életkorú, élethelyzetü emberek és csoportok olvasásfejlesztését támogatják; képessé válnak egyének, közösségek körében ezek tudatos alkalmazásra.

A könyvtárosok teljesitménymérése és digitális kompetenciái tanfolyam elvégzése lehetőséget biztosít arra, hogy a résztvevők jártasságot szerezzenek a teljesítménymérés (TÉR) módszereinek bevezetésében, működtetésében és felülvizsgálatában, a könyvtári területen már kialakult jó gyakorlatok alkalmazásában, a vonatkozó dokumentáció elkészítésében és folyamatos karbantartásában. A képzés során a résztvevők megismerik a digitális kompetencia keretrendszereit, elsajátítják e kompetencia mérési módszereit, képessé válnak az internetes veszélyek kiküszöbölésére, a felhő alapú online könyvtári szolgáltatások alkalmazására, és megismerik az open access publikálás gyakorlatát.

Tanfolyami kínálatunk most már lefedi a könyvtári tájékoztatás és információellátás valamennyi területét: a már korábban is müködtetett Általános és szaktájékoztatás (társadalomtudomány, szociológia, müvészet, történelem, jog) online adatbázisokkal címü képzés mellett megújítottuk az Irodalmi tájékoztatás online források alapján elnevezésủ tanfolyam engedélyét, újonnan engedélyeztettük a Kutatástámogatás könyvtári környezetben: szakirodalmi, tudománymetriai 
és statisztikai adatbázis-használat és a Müszaki és természettudományos szaktájékoztatás felsőfokon elnevezésű képzéseket.

Az internet archiválása mint közgyüjteményi feladat címü tanfolyam célja, hogy a résztvevők megismerjék az internetes tartalmak hosszú távú megőrzésére alkalmas technikákat, az ezzel foglalkozó külföldi projekteket és az Országos Széchényi Könyvtárban ellátott központi webarchiválási tevékenységet. A kurzus elvégzése után a résztvevők jártassá válnak weboldalakat és webhelyeket tartalmazó intézményi gyüjtemények létrehozásában, és elsajátítják a magyar internet-archívummal kapcsolatos feladatok alapjait annak érdekében, hogy képesek legyenek bekapcsolódni a közös archiválási munkába.

Felkészülés a fogyatékossággal élök korszerü könyvtári ellátására elnevezésü képzésünk során a különbözö fogyatékosság-típusokhoz kapcsolható speciális kommunikációs helyzetek és a kommunikációs folyamatok során alkalmazott módszerek megismerése mellett a résztvevők elsajátítják a speciális eszközök használatát, a könyvtári hozzáférés fizikai és tartalmi akadálymentesítésének feltétel- és feladatrendszerét, felmérik a vonatkozó könyvtári kutatási eredmények tapasztalatait és tanulságait, a fogyatékossággal élők könyvtári esélyeinek javítása érdekében jártasságot szereznek a kapcsolatépítésben, a hagyományos és IKTszolgáltatások szervezésében, jó gyakorlatok kialakításában és alkalmazásában.

Ahhoz, hogy a könyvtárosok megismerjék a könyvtári marketing alapjait, elsajátítsák az egységes intézményi arculat és kapcsolatrendszer, a sajtó- és médiamegjelenések kialakításának módszereit, a könyvtárak közösségi médiához való kapcsolódásának lehetőségeit, Úton a felhasználók felé - könyvtári marketing és rendezvényszervezés címmel engedélyeztettünk képzést a közelmúltban. A résztvevők a képzés során bevezetést kapnak a közérthető fogalmazás és az asszertív kommunikáció ismereteibe, képessé válnak új könyvtári szolgáltatások marketingjének megtervezésére, elsajátítják a rendezvényszervezés folyamatának lépéseit.

Komoly kihívást jelent a könyvtárak számára az Európai Unió által elfogadott GDPR-rendeletnek ${ }^{14}$ való megfelelés. A rendelet elő́rásai zökkenőmentes alkalmazásának érdekében a kollégák $A$ GDPR szabályainak megfelelö adatkezelés a könyvtárakban címü tanfolyamon vehetnek részt, ahol megismerik a személyesadat-védelem kialakulását és a korszerü adatvédelmi elveket, jogszabályokat, az adatvédelem európai uniós és hazai hatósági rendszerét. A kurzust sikeresen elvégzők tisztában lesznek a GDPR céljával, hatályával, alapfogalmaival,

${ }^{14}$ Az Európai Parlament és a Tanács (EU) 2016/679 rendelete (2016. április 27.) a természetes személyeknek a személyes adatok kezelése tekintetében történő védelméről és az ilyen adatok szabad áramlásáról, valamint a 95/46/EK irányelv hatályon kívül helyezéséről (általános adatvédelmi rendelet). https:/eur-lex.europa.eu/legal-content/HU/TXT/HTML/?uri=CELEX:02016R067920160504\&from=HU (2019. október 4.) 
a könyvtári szolgáltatásokat érintő rendelkezéseivel, elsajátítják a jogszerü adatkezelés elveit, megismerik a jó gyakorlatokat, és megértik a szabályozás informatikai vonatkozásait.

Gyermekkönyvtári ismeretek új kihívásokkal címü képzésünk kiegészítő címe: Most Te is beolvashatsz! A gyerekkönyvtárosokra számító továbbképzés célja a gyermekirodalmi kitekintés és a gyermekkönyvtári munka megújult alapjainak megismertetése mellett az, hogy a gyakorlatban jól alkalmazható módszertani kínálatot nyújtson ahhoz: milyen stratégiával fordíthatók a gyermekek az olvasmányélmények megszerzése felé, milyen programok vonzzák be őket a könyvtárba. A képzés elvégzése után a könyvtárosok jártassá válnak a dráma- és élménypedagógiai módszerek, az egyéniségüknek leginkább megfelelő jó gyakorlatok alkalmazásában, képesek lesznek a folyamatos eszközhasználati megújulásra, az örömteli munkavégzésre.

Elsősorban zenei könyvtárosokat, médiatárosokat és rendezvényszervezö kollégákat várunk $A$ zeneirodalom csúcspontjai könyvtáros szemmel elnevezésü képzésünkre, amely a zeneirodalom néhány reprezentánsának bemutatásával zenetörténeti, hangszerismereti, stílus- és forrásismeretet nyújt, konkrét zeneművek példáin keresztül rámutat az egyes zenei korszakok és müfajok jellegzetességeire. A művek meghallgatása mellett sor kerül elemzésükre, a vonatkozó kotta- és képanyag bemutatására, a kapcsolódó szakirodalom ismertetésére annak érdekében, hogy a résztvevők jártasságot szerezzenek a zenei formák ismeretében, fejlesszék zenei tájékoztatási képességüket, és képesek legyenek zenei elemeket is tartalmazó rendezvény szervezésére.

\section{Számszerü eredmények a továbbképzések területén}

2017 júniusa és 2019 júniusa között a tanfolyamok döntő többségét az akkreditációs engedélyben megszabott teljes létszámban vagy azt közelítve indítottuk el, az ország teljes területéről összesen 1350 kolléga - ez a legalább hatórás szakmai munkakörben dolgozó könyvtárosok mintegy 27,14 százaléka - vett részt a képzéseken. Az őket delegáló intézmények valamennyi könyvtártípust képviselték, és a résztvevők szinte 100 százaléka teljesítette a tanúsítvány megszerzéséhez előírt követelményeket.

\begin{tabular}{|l|c|}
\hline \multicolumn{1}{|c|}{ A továbbképzés elnevezése, óraszáma } & $\begin{array}{c}\text { Tanfolyami alkalmak } \\
\text { száma / résztvevők } \\
\text { száma }\end{array}$ \\
\hline $\begin{array}{l}\text { Államháztartási és vezetési ismeretek többfunkciós kulturális } \\
\text { intézmények vezetői számára (60 óra) }\end{array}$ & 2 alkalom / 33 fö \\
\hline $\begin{array}{l}\text { Általános és szaktájékoztatás (társadalomtudomány, szocio- } \\
\text { lógia, múvészet, történelem, jog) online adatbázisokkal (60 } \\
\text { óra) }\end{array}$ & 3 alkalom / 43 fö \\
\hline
\end{tabular}




\begin{tabular}{|c|c|}
\hline $\begin{array}{l}\text { Angol szaknyelvi ismeretek könyvtárosoknak (60 óra: } 50 \\
\text { kontaktóra }+10 \text { óra otthoni munka) }\end{array}$ & 4 alkalom / 52 fö \\
\hline Coaching szemlélettel a könyvtárban (30 óra) & 1 alkalom / 14 fö \\
\hline $\begin{array}{l}\text { Elektronikus tananyagfejlesztés és távoktatás könyvtári kör- } \\
\text { nyezetben ( } 60 \text { óra: } 30 \text { kontaktóra }+30 \text { óra távoktatás) }\end{array}$ & 4 alkalom / 78 fö \\
\hline $\begin{array}{l}\text { Felkészülés a fejlesztő biblioterápia könyvtári alkalmazására } \\
\text { (60 óra) }\end{array}$ & 8 alkalom / 95 fö \\
\hline $\begin{array}{l}\text { Felkészülés a fogyatékossággal élők korszerủ könyvtári ellá- } \\
\text { tására (60 óra) }\end{array}$ & 1 alkalom / 13 fö \\
\hline $\begin{array}{l}\text { Felkészülés az iskolai közösségi szolgálat fogadására a köz- } \\
\text { gyüjteményekben (30 óra) }\end{array}$ & 1 alkalom / 18 fö \\
\hline $\begin{array}{l}\text { A GDPR szabályainak megfelelő adatkezelés a könyvtárak- } \\
\text { ban ( } 30 \text { óra }\end{array}$ & 1 alkalom / 18 fö́ \\
\hline $\begin{array}{l}\text { Gyermekkönyvtári ismeretek új kihívásokkal - Most Te is be- } \\
\text { olvashatsz! (60 óra) }\end{array}$ & 2 alkalom / 28 fö \\
\hline Az internet archiválása mint közgyüjteményi feladat (30 óra) & 1 alkalom / 23 fö \\
\hline Irodalmi tájékoztatás online források alapján (45 óra) & 2 alkalom / 30 fö \\
\hline Kiadványszerkesztés könyvtári környezetben (90 óra) & 3 alkalom / 59 fö \\
\hline $\begin{array}{l}\text { Konstruktív konfliktuskezelés hatékony tárgyalási technikák- } \\
\text { kal (30 óra) }\end{array}$ & 9 alkalom / 103 fö \\
\hline A korszerü helyismereti munka alapjai (60 óra) & 4 alkalom / 65 fö \\
\hline $\begin{array}{l}\text { A könyvtárak minősítése és a Könyvtári Közös Értékelési Ke- } \\
\text { retrendszer ( } 60 \text { óra) }\end{array}$ & 1 alkalom / 25 fö \\
\hline $\begin{array}{l}\text { Könyvtári partnerkapcsolatok (szervezeti kultúra, szakmai } \\
\text { önismeret) (30 óra) }\end{array}$ & 7 alkalom / 98 fö \\
\hline Könyvtári szakértői ismeretek (30 óra) & 4 alkalom / 74 fö \\
\hline Könyvtári vezetési ismeretek (120 óra) & 2 alkalom / 45 fö \\
\hline $\begin{array}{l}\text { A könyvtárosok teljesítménymérése és digitális kompetenciái } \\
\text { (60 óra) }\end{array}$ & 1 alkalom / 19 fö \\
\hline A kulturális közösségfejlesztés gyakorlata (60 óra) & 2 alkalom / 40 fö \\
\hline $\begin{array}{l}\text { A kulturális közösségfejlesztés gyakorlata (blended) (60 óra: } \\
30 \text { kontaktóra }+30 \text { óra távoktatás) }\end{array}$ & 2 alkalom / 106 fö \\
\hline $\begin{array}{l}\text { Kutatástámogatás könyvtári környezetben: szakirodalmi, } \\
\text { tudománymetriai és statisztikai adatbázis-használat (45 óra) }\end{array}$ & 2 alkalom / 31 fö \\
\hline $\begin{array}{l}\text { Müszaki és természettudományos szaktájékoztatás felsőfo- } \\
\text { kon (45 óra) }\end{array}$ & 1 alkalom / 18 fö \\
\hline $\begin{array}{l}\text { Olvasásösztönzés, olvasásnépszerüsítés, olvasásfejlesztés (60 } \\
\text { óra) }\end{array}$ & 6 alkalom / 88 fö \\
\hline $\begin{array}{l}\text { A szerzöi jog a könyvtárakban ( } 30 \text { óra: } 12 \text { kontaktóra }+18 \\
\text { óra távoktatás) }\end{array}$ & 4 alkalom / 104 fö \\
\hline
\end{tabular}




\begin{tabular}{|l|c|}
\hline $\begin{array}{l}\text { Zenei könyvtári ismeretek III. - feltárás - tájékoztatás - új } \\
\text { technológiák (60 óra) }\end{array}$ & 1 alkalom / 16 fö \\
\hline A zeneirodalom csúcspontjai könyvtáros szemmel (30 óra) & 1 alkalom / 14 fö \\
\hline Összesen: & 80 alkalom / 1350 fö \\
\hline
\end{tabular}

2. táblázat. A Könyvtári Intézet által megvalósított továbbképzések, 2017. június - 2019. június

A minisztériumi támogatás lehetőséget biztosított arra, hogy az Intézeten kívül más budapesti és vidéki helyszíneken - megyei hatókörű városi könyvtárakban, felsőoktatási és országos szakkönyvtárakban - szervezze meg a tanfolyamok egy részét. Oktatóink és tanfolyamfelelöseink összesen 24 alkalommal utaztak el az előre egyeztetett helyszínekre, a résztvevői létszám összegyüjtésében és a tanfolyami adminisztráció lebonyolításában pedig mindig segítséget kaptunk a helyszínt biztosító intézményi kollégáktól.

\begin{tabular}{|c|c|}
\hline A tanfolyam elnevezése & A tanfolyam helyszíne \\
\hline $\begin{array}{l}\text { Angol szaknyelvi ismeretek könyv- } \\
\text { tárosoknak }\end{array}$ & $\begin{array}{l}\text { Csorba Győző Könyvtár, Pécs - Dél-dunántúli } \\
\text { Regionális Könyvtár és Tudásközpont, Pécs }\end{array}$ \\
\hline $\begin{array}{l}\text { Felkészülés a fejlesztő biblioterápia } \\
\text { könyvtári alkalmazására }\end{array}$ & $\begin{array}{l}\text { Hamvas Béla Pest Megyei Könyvtár, Szentendre } \\
\text { ( } 8 \text { alkalom) }\end{array}$ \\
\hline \multirow{5}{*}{$\begin{array}{l}\text { Konstruktív konfliktuskezelés haté- } \\
\text { kony tárgyalási technikákkal }\end{array}$} & $\begin{array}{l}\text { Somogyi Károly Városi és Megyei Könyvtár, } \\
\text { Szeged }\end{array}$ \\
\hline & Csorba Győző Könyvtár, Pécs (2 alkalom) \\
\hline & ELTE Egyetemi Könyvtár és Levéltár, Budapest \\
\hline & SZTE Klebelsberg Kuno Könyvtára, Szeged \\
\hline & BME OMIKK, Budapest \\
\hline $\begin{array}{l}\text { A korszerü helyismereti munka } \\
\text { alapjai }\end{array}$ & Verseghy Ferenc Könyvtár, Szolnok \\
\hline \multirow{3}{*}{ Könyvtári partnerkapcsolatok } & Vörösmarty Mihály Könyvtár, Székesfehérvár \\
\hline & Fővárosi Szabó Ervin Könyvtár, Budapest \\
\hline & II. Rákóczi Ferenc Megyei Könyvtár, Miskolc \\
\hline \multirow{4}{*}{$\begin{array}{l}\text { Olvasásösztönzés, olvasásnépszerü- } \\
\text { sítés, olvasásfejlesztés }\end{array}$} & Békés Megyei Könyvtár, Békéscsaba \\
\hline & $\begin{array}{l}\text { Hamvas Béla Pest Megyei Könyvtár, Szentendre } \\
(2 \text { alkalom) }\end{array}$ \\
\hline & $\begin{array}{l}\text { ELTE Savaria Regionális Pedagógiai Szolgáltató } \\
\text { és Kutató Központ, Szombathely }\end{array}$ \\
\hline & Méliusz Juhász Péter Könyvtár, Debrecen \\
\hline $\begin{array}{l}\text { A zeneirodalom csúcspontjai könyv- } \\
\text { táros szemmel }\end{array}$ & Országos Idegennyelvü Könyvtár, Budapest \\
\hline
\end{tabular}

3. táblázat. A Könyvtári Intézet kihelyezett továbbképzései, 2017. június - 2019. június 
A továbbképzések listája a Könyvtári Intézet közelmúltban megújult honlapjának Képzés menüpontjában az Engedélyezett továbbképzések oldalon ${ }^{15}$ érhetö el olyan módon, hogy az egyes képzések leírásából azonnal kezdeményezhető az elektronikus jelentkezés is. A tanfolyamokról átfogó képet a menüpontból letölthető formában elérhető képzési terv ${ }^{16} \mathrm{ad}$, amelynek szerkezetében az Intézet az idei évtől tért át a naptári évesről a tanéves formára - tehát júliustól már a 2020as év tavaszi félévének képzési időpontjaira is jelentkezhetnek az érdeklődő könyvtáros kollégák. A képzési terv az intézeti helyszíniek mellett tartalmazza a vidéki helyszínekre elöre egyeztetett tanfolyami időpontokat is. A továbbképzési programok nyilvántartásba vételi szabályairól szóló új rendelet elöírja a képzőintézmények számára a programok minőségbiztosításával kapcsolatos, egész éves tevékenység tapasztalatainak összegzését, az egyes képzések résztvevőinek a program tartalmával és lebonyolításával kapcsolatos elégedettségéről szóló - anonim kérdőívek válaszai alapján készített - összesítést és mindezeknek az intézmény honlapján való megjelenítését. ${ }^{17}$ Ezeknek a kötelezettségeknek a Könyvtári Intézet folyamatosan és a határidőket betartva eleget tesz. ${ }^{18}$

\section{Rezümé}

A negyedik ipari forradalom kihívásai a könyvtárosokat is kompetenciáik fejlesztésére ösztönzik. 2018 elején megújult a kulturális szakemberek továbbképzésére vonatkozó jogszabályi környezet, az állami költségvetésben az utóbbi években újra megjelent a továbbképzéseket támogató költségvetési sor, mindez komoly lendületet adott a könyvtáros kompetenciák képzéseken keresztüli erősítésének. A támogatásnak köszönhetöen és a nyilvános könyvtárak körében lefolytatott igényfelmérés alapján a Könyvtári Intézet kontakt és blended képzések engedélyeztetésével növelte és megújította továbbképzési kínálatát, és a könyvtáros kollégák számára ingyenes részvételi lehetőséget biztosít mind a székhelyén újonnan kialakított hagyományos és számítógépes oktatótermekben, mind a képzéseket befogadó budapesti és vidéki helyszíneken szervezett tanfolyamain.

${ }^{15}$ L. https://ki.oszk.hu/kepzes/engedelyezett-tovabbkepzesek (2019. október 4.)

${ }^{16}$ L. https://ki.oszk.hu/dokumentumtar/kepzesi-terv-20192020 (2019. október 4.)

17 378/2017. (XII. 11.) Korm. rendelet a kulturális szakemberek szakmai továbbképzésének nyilvántartásba vétel szabályairól, 8. §, 7. § (6) bek. http://njt.hu/cgi_bin/njt_doc.cgi?docid= 205785.347559 (2019. október 4.)

${ }^{18}$ A 2018-as év képzési összefoglalóját 1. https://ki.oszk.hu/sites/default/files/csatoltfajlok/ tk_programok_2018_minbizt_osszefoglalo.pdf; az egyes tanfolyamok elégedettségre vonatkozó összesítésének helye az adott képzés hirdetési oldala, a képzés rövid szöveges leírása alatt, 1. pl. https://ki.oszk.hu/sites/default/files/csatoltfajlok/honlap_bibl_uj_9.pdf(2019. október 4.) 


\section{Strengthening the competences of librarians}

\section{Extension training courses offered by the Hungarian Library Institute}

The challenges of the Fourth Industrial Revolution encourage librarians as well to develop their competences. In early 2018, a new legal regulation on the extension training of cultural workers was issued in Hungary, and in recent years a line supporting extension training has been included in the state budget again. All this gave a major impetus to strengthening the competences of librarians through training. Thanks to this state support, and based on a needs assessment conducted in libraries open to the wider public, the Hungarian Library Institute has increased and upgraded its offer of extension training courses, and provides now an opportunity for librarians to participate, free of charge, at courses organized in the new - traditional and computer-based - instruction rooms at its site, as well as at other locations both in Budapest and in other towns.

HANGODI ÁGNES

osztályvezető

Országos Széchényi Könyvtár Könyvtári Intézet

ORCID: 0000-0003-3795-9648 